\title{
Eksistensi Peraturan Mahkamah Agung No. 02 Tahun 2012 tentang Penyesuaian Batasan Tindak Pidana Ringan dan Jumlah Denda dalam KUHP
}

\author{
N. Okamahendra \\ Mahasiswa Program Studi Magister Ilmu Hukum Universitas Mataram \\ Email: okamahendra@gmail.com
}

\begin{abstract}
ABSTRAK
Penetian ini bertujuan untuk mengetahui dan menganalisis eksistensi PERMA No. 02 Tahun 2012 tentang Penyesuaian Batasan Tindak Pidana Ringan dan Jumlah Denda Dalam KUHP dengan ruang lingkup sebatas mengkaji dan menganalisis eksistensi PERMA No. 02 Tahun 2012. Penelitian ini merupakan penelitian hukum normatif. Pendekatan yang digunakan adalah pendekatan perundangundangan, pendekatan konseptual, pendekatan filsafat, dan pendekatan kasus. Tehnik pengumpulan bahan hukum dengan studi kepustakaan. Setelah itu dilakukan pengolahan bahan hukum dengan mengadakan sistemtisasi kemudian dilakukan penalaran secara logis, sistematis, dan interpretatif dengan analisa deskriptif analistis dan menarik kesimpulan dengan cara deduktif. Secara substantial ketentuan-ketentuan dalam PERMA No. 02 Tahun 2012 telah mengkonversi konsep Tindak Pidana Ringan khususnya pada batasan nilai obyek kerugian perkara menjadi Rp. 2.500.000,- (dua juta lima ratus ribu rupiah) dan atau denda sebanyak-banyaknya tujuh juta lima ratus ribu rupiah dan penghinaan ringan. Pasal-pasal dalam KUHP yang dikonversi dalam PERMA tersebut adalah 364, 373, 379, 384, 407 ayat (1) dan 482 KUHP. Kedudukan PERMA dalam hierarki Peraturan Perundangundangan di Indoensia adalah sebagai aturan khusus (interne regeling) karena daya ikatnya yang hanya mencakup lingkungan suatu lembaga sehingga tidak memiliki keberlakuan bagi instansi lain serta memiliki konsekuensi yuridis.
\end{abstract}

Kata Kunci: Eksistensi, Peraturan Mahkamah Agung, Tindak Pidana Ringan

\section{ABSTRACT}

This research to know and analyze the existence of PERMA No. 02 Year 2012 on Adjustment of Limitation of Criminal Act and Number of Penalties in Criminal Code with limited scope to review and analyze the existence of PERMA No. 02 Year 2012. This research is normative law research. The approach used is the approach of legislation, conceptual approach, philosophy approach, and case approach. Technique of collecting legal material with literature study. After that the processing of legal materials by systematization and then done logical, systematic, and interpretative reasoning with analytical descriptive analysis and draw deductive conclusions. Substantially the provisions in PERMA No. O2 Year 2012 has converted the concept of Criminal Crime especially on the limit of 
object value of loss of case to Rp. 2.500.000, - (two million five hundred thousand rupiah) and or a fine of up to seven million five hundred thousand rupiah and minor insult. The Articles of the Penal Code converted in the PERMA are 364, 373, 379, 384, 407 paragraph (1) and 482 of the Criminal Code. The position of PERMA in the hierarchy of the Laws and Regulations in Indonesia is as an internal regulation because of its binding power which only covers the environment of an institution so that it has no validity for other agencies and has juridical consequences.

Keywords: Existence, Supreme Court Regulations, Minor Crimes.

\section{A. PENDAHULUAN}

Eksistensi beberapa ketentuan dalam KUHP dirasa sudah tidak memenuhi kebutuhan hukum dalam perkembangan kehidupan masyarakat Indonesia khususnya terkait dengan batasan tindak pidana ringan dan jumlah denda. Untuk mengisi kekosongan hukum pada saat itu, pemerintah mengeluarkan Perpu No. 16 Tahun 1960 tentang Beberapa Perubahan Dalam KUHP. Ketentuan yang diubah tersebut terkait dengan Tindak Pidana Ringan sebagaimana diatur dalam Pasal 364, 373, 379, 384, 407 ayat (1) dan 482 KUHP. Dengan dikeluarkannya Perpu tersebut ketentuan nilai barang dalam perkara Tindak Pidana Ringan diubah menjadi dua ratus lima puluh rupiah yang sebelumnya hanya bernilai dua puluh lima rupiah. Landasan Sosiologis diberlakukannya Perpu ini terdapat pada Tambahan Lembaran Negara Nomor 1976 alinea keenam yang berbunyi:

"Harus diakui bahwa harga Rp. 25,- itu tidak sesuai lagi dengan keadaan sekarang dimana harga barang-barang telah membubung tinggi, banyak kali lipat, jauh melebihi harga-harga barang pada kira-kira tahun 1915, ialah tahun ketika Kitab Undangundang Hukum Pidana direncanakan, sehingga nilai uang Rp. 25,- itu sekarang merupakan jumlah yang kecil sekali. Maka sewajarnya jumlah uang Rp. 25,- itu dinaikkan sedemikian hingga sesuai dengan keadaan sekarang. Jumlah yang selayaknya untuk harga barang dalam pasal-pasal itu menurut pendapat Pemerintah ialah Rp. 250,-“. ${ }^{1}$

Sejak dikeluarkannya Perpu No. 16 Tahun 1960 sampai dengan akhir tahun 2011, pemerintah belum juga melakukan penyesuaian kembali terhadap nilai rupiah pada batasan Tindak Pidana Ringan dan jumlah denda dalam KUHP tersebut. Sikap pemerintah yang pasif inilah yang kemudian berimplikasi terhadap efektifitas pasal-pasal yang mengatur Tindak Pidana Ringan, karena pada kenyataannya dari apa yang dapat dirasakan atau diamati langsung (empiris) melalui media cetak, media elektronik atau sumber informasi lainnya, hampir tidak ada kasus-kasus yang terjadi dalam teritorial Negara Indonesia yang memiliki objek perkara yang bernilai dua ratus lima puluh rupiah. Kasus pencurian 3 buah kakao oleh nenek Minah yang terjadi pada tahun 2009 yang divonis oleh hakim dengan hukuman penjara selama 1 bulan 15 hari dengan masa percobaan 3 bulan karena secara sah dan meyakinkan telah melanggar ketentuan dalam Pasal 362 KUHP dan beberapa kasus serupa lainnya, kemudian muncul ke permukaan dan mendorong para penegak hukum untuk lebih berlaku adil dan mempertimbangkan rasa keadilan terhadap pelaku-pelaku tersebut. Karena apabila dikaji dari nilai objek perkara, sebenarnya tidak seberapa namun harus diganjar dengan hukuman yang tidak sebanding.

Untuk mengatasi problematika tersebut, pada akhirnya pemerintah melalui Mahkamah Agung sebagai Lembaga Tinggi Negara, mengeluarkan Peraturan Mahkamah Agung No. 02 Tahun 2012 tentang Penyesuaian Batasan Tindak Pidana Ringan dan Jumlah Denda Dalam

${ }^{1}$ Indonesia, Peraturan Pemerintah Pengganti Undang-Undang No. 16 tahun 1960 tentang Beberapa Perubahan Dalam KUHP, Tambahan Lembaran Negara No. 1976. 
KUHP. Pasal 1 PERMA tersebut mengatur nilai barang dalam Pasal 364 KUHP (pencurian ringan), 373 (penggelapan ringan), 379 (penipuan ringan), 384 (penipuan ringan oleh penjual), 407 ayat (perusakan ringan), dan Pasal 482 (penadahan ringan) menjadi Rp. 2.500.000,- (dua juta lima ratus ribu rupiah) dari yang semula hanya bernilai Rp. 250,- (dua ratus lima puluh rupiah). ${ }^{2}$ Dengan demikian maka ancaman hukuman tindak pidana yang memenuhi pasal-pasal tersebut di atas menjadi maksimal 3 bulan penjara sehingga tidak perlu ditahan sebagaimana diatur dalam Pasal 21 KUHAP.

Disamping mengatur mengenai penyesuaian nilai barang dalam KUHP, PERMA juga mengatur mengenai penyesuaian nilai denda dan criminal procedure dalam pasal-pasal tertentu dalam KUHP. Pasal-pasal yang dimaksud kecuali Pasal 303 ayat (1) dan (2) serta 303 bis ayat (1) dan (2) dengan nilai denda yang dilipatgandakan menjadi 1.000 (seribu) kali lipat ${ }^{3}$ dan terhadap tersangka/terdakwa tidak dapat dilakukan penahanan dan perpanjangan penahanan oleh Hakim dan Ketua Pengadilan sebagaimana yang diatur dalam Pasal 2 ayat (3) Peraturan Mahkamah Agung No. 2 Tahun 2012.

Berdasarkan sifatnya, PERMA merupakan salah satu peraturan perundang-undangan yang bersifat khusus karena kekhususan daya ikat materinya, yaitu hanya berlaku internal (interne regeling). ${ }^{5}$ Dalam Pasal 15 ayat (1) Undang-Undang No. 12 Tahun 2011 tentang Pembentukan Peraturan Perundang-Undangan menjelas-kan bahwa:

"Materi muatan mengenai ketentuan pidana hanya dimuat dalam:

a. Undang-Undang;

b. Peraturan Daerah Provinsi; atau

c. Peraturan Daerah Kabupaten/Kota". 6

Sedangkan, dalam Pasal 7 ayat (1), berbunyi:

"Jenis dan hirarki Peraturan Perundang-undangan terdiri atas:

1. Undang-Undang Dasar Negara Republik Indonesia Tahun 1945;

2. Ketetapan Majelis Permusyawaratan Rakyat;

3. Undang-Undang/Peraturan Pemerintah Pengganti Undang-Undang;

4. Peraturan Pemerintah;

5. Peraturan Presiden;

6. Peraturan Daerah Provinsi; dan

7. Peraturan Daerah Kabupaten dan Kota". 7

Pada kajian Pasal 15 ayat (1) dan Pasal 7 ayat (1) Undang-Undang No. 12 Tahun 2011 tentang Pembentukan Peraturan Perundang-Undangan tersebut di atas, nampak jelas bahwa telah terjadi konflik norma secara vertikal antara Peraturan Mahkamah Agung No. 02 Tahun

\footnotetext{
${ }^{2}$ Indonesia, Peraturan Mahkamah Agung No. 2 Tahun 2012 tentang Penyesuaian Batasan Tindak Pidana Ringan dan Jumlah Denda Dalam KUHP, Psl. 1.

${ }^{3}$ Indonesia, Peraturan Mahkamah Agung No. 2 Tahun 2012 tentang Penyesuaian Batasan Tindak Pidana Ringan dan Jumlah Denda Dalam KUHP, Psl. 3

${ }^{4}$ Indonesia, Peraturan Mahkamah Agung No. 2 Tahun 2012 tentang Penyesuaian Batasan Tindak Pidana Ringan dan Jumlah Denda Dalam KUHP, Psl. 2 ayata (3).

${ }^{5}$ Jimly Asshiddiqie, Perihal Undang-Undang, Cetakan Pertama, PT. Rajagrafindo Persada, Jakarta, hlm. 13

${ }^{6}$ Indonesia, Undang-Undang tentang Pembentukan Peraturan Perundang-undangan, UU No. 12 Tahun 2011, LN No. 82 Tahun 2011, TLN No. 5234 Tahun 2011, Psl. 15 ayat (1)

${ }^{7}$ Indonesia, Undang-Undang tentang Pembentukan Peraturan Perundang-Undangan, UU No. 12 Tahun 2011, LN No. 82 Tahun 2011, TLN No. 5234 Tahun 2011, Psl. 7 ayat (1)
} 
2012 tentang Penyesuaian Batasan Tindak Pidana Ringan dan Jumlah Denda Dalam KUHP dan Undang-Undang No. 12 Tahun 2011 tentang Pembentukan Peraturan PerundangUndangan. Hal tersebut menimbulkan pertanyaan mengenai eksistensi Peraturan Mahkamah Agung tersebut khususnya mengenai validitas dan keberlakuannya dalam Sistem Peradilan Pidana Terpadu.

Untuk menjawab permasalahan yang diajukan digunakan pendekatan perundangundangan (Statute Approach), pendekatan konseptual (Conceptual Approach), pendekatan filsafat (Philosophical Approach) dan pendekatan kasus (Case Approach). Penelitian ini hanya mengkaji dan menganalisis eksistensi Peraturan Mahkamah Agung No. 02 Tahun 2012 tentang Penyesuaian Batasan Tindak Pidana Ringan dan Jumlah Denda Dalam KUHP. Orisinalitas penelitian ini yakni mengkaji secara mendalam PERMA No. 02 Tahun 2012 dari perspektif kebijakan hukum, tujuan hukum, hukum responsif, dan keadilan restoratif. Penelitian ini diharapkan menjadi referensi bagi para penegak hukum / praktisi hukum dalam penanganan Tindak Pidana Ringan serta dapat menambah hasanah ilmu pengetahuan.

\section{B. PEMBAHASAN}

Eksistensi Peraturan Mahkamah Agung (PERMA) No. 02 Tahun 2012 tentang Penyesuaian Batasan Tindak Pidana Ringan dan Jumlah Denda Dalam KUHP dalam Sistem Peradilan Pidana bertendensi terjadinya distorsi hukum. Kajian substantial yang secara tidak langsung mentransformasi beberapa Pasal dalam KUHP dan KUHAP berimplikasi terhadap penanganan perkara-perkara ringan dalam tahapan-tahapan peradilan. Berikut beberapa kajian terkait Eksistensi Peraturan Mahkamah Agung No. 02 Tahun 2012 Tentang Penyesuaian Batasan Tindak Pidana Ringan Dan Jumlah Denda Dalam KUHP, sebagai berikut:

\section{Terminologi Tindak Pidana Ringan}

Istilah Tindak Pidana Ringan merupakan terjemahan dari kata "lichte misdrijven" yang secara kontekstual diatur dalam Wetbook van Strafrecht vor Nederlandsch Indie (W.v.S.v. NI) yakni Code Penal / KUHP Belanda yang diberlakukan di Indonesia sejak tahun 1918 berdasarkan asas konkordansi yang mulai berlaku pada tanggal 1 Januari $1918 .^{8}$ Definisi Tindak Pidana Ringan telah terkonsep secara materil dan formil yang diatur dalam KUHP (Kitab Undang-Undang Hukum Pidana) maupun KUHAP (Kitab Undang-Undang Hukum Acara Pidana). Pada bulan Februari tahun 2012, Mahkamah Agung mengeluarkan Peraturan Mahkamah Agung No. 02 Tahun 2012 tentang Penyesuaian Batasan Tindak Pidana Ringan Dalam KUHP. Ketentuan-ketentuan dalam PERMA tersebut kemudian secara konseptual mengkonversi pengertian Tindak Pidana Ringan yakni perkara yang diancam dengan pidana penjara atau kurungan paling lama tiga bulan dengan nilai obyek perkara di bawah $\mathrm{Rp}$. 2.500.000,- (dua juta lima ratus ribu rupiah) dan atau denda sebanyak-banyaknya tujuh juta lima ratus ribu rupiah dan penghinaan ringan. Pasal-pasal dalam KUHP yang dikonversi dalam PERMA tersebut adalah 364, 373, 379, 384, 407 ayat (1) dan 482 KUHP. Perubahan konsep Tindak Pidana Ringan oleh Mahkamah Agung secara langsung akan mengintervensi Sistem Peradilan Pidana Terpadu di Indonesia mengingat kajian substansial PERMA No. 02 Tahun 2012 tersebut.

\section{Kedudukan Peraturan Mahkamah Agung No. 02 Tahun 2012 dalam Peraturan Perundang-Undangan.}

Pasal 7 ayat (1) Undang-Undang No. 12 Tahun 2011 tentang Pembentukan Peratuturan Perundang-undangan, berbunyi:

${ }^{8}$ Amiruddin, Keabsahan Perubahan dan Penambahan Peraturan Hukum Pidana melalui PERPPU Dan PERMA, ARENA HUKUM Volume 6, Nomor 3, Universitas Mataram, 2012, hlm. 156. 
"Jenis dan hierarki Peraturan Perundang-undangan terdiri atas:

1. Undang-Undang Dasar Negara Republik Indonesia Tahun 1945;

2. Ketetapan Majelis Permusyawaratan Rakyat;

3. Undang-Undang/Peraturan Pemerintah Pengganti Undang-Undang;

4. Peraturan Pemerintah;

5. Peraturan Presiden;

6. Peraturan Daerah Provinsi; dan

7. Peraturan Daerah Kabupaten dan Kota". 9

Pasal 8 ayat (1) Undang-Undang No. 12 Tahun 2011 yang berbunyi:

"Jenis Peraturan Perundang-undangan selain yang telah ditentukan pada Pasal 7 ayat (1) mencakup peraturan Mahkamah Agung, Mahkamah Konstitusi, Badan Pemeriksa Keuangan, Komisi Yudisial, Bank Indonesia, Menteri, Badan, Lembaga, atau ditetapkan oleh Majelis Permusyawaratan Rakyat, Dewan Perwakilan Rakyat, Dewan Perwakilan Daerah, Mahkamah komisi yang setingkat yang dibentuk dengan Undang-Undang atau Pemerintah atas perintah Undang-Undang, Dewan Perwakilan Rakyat Daerah Provinsi, Gubernur, Dewan Perwakilan Rakyat Daerah Kabupaten/Kota, Bupati/Walikota, Kepala Desa atau yang setingkat". 10

Dengan demikian, Lembaga Tinggi Negara lainnya seperti Mahkamah Agung memiliki landasan yuridis dalam membuat suatu Peraturan Perundang-undangan, yakni Peraturan Mahkamah Agung yang biasanya disingkat dengan kata PERMA.

Menurut Jimly Asshiddiqie, PERMA termasuk kategori keempat dari empat kategori peraturan tertulis, yaitu Peraturan perundang-undangan yang bersifat khusus karena kekhususan daya ikat materinya, yaitu hanya berlaku internal (interne regeling/internal regulation). ${ }^{11}$

Mahkamah Agung diberi kewenangan mengatur secara internal dengan menetapkan Peraturan Mahkamah Agung (PERMA) untuk tujuan kelancaran pelaksanaan tugas dan wewenangnya menurut Pasal 24A ayat (1) Undang-Undang Dasar Negara Republik Indonesia Tahun 1945, dan Pasal 79 Undang-Undang No. 3 Tahun 2009 tentang Mahkamah Agung.

Meskipun secara teoritis dikatakan bahwa sifat regulasi yang ditetapkan dalam bentuk PERMA hanya bersifat internal, tetapi salah satu produk hukum dari Mahkamah Agung, yakni PERMA No. 2 Tahun 2012 tentang Penyesuaian Batasan Tindak Pidana Ringan dan Jumlah Denda Dalam KUHP sedikit banyak bersentuhan dengan subjek-subjek hukum (legal subjects) di luar Mahkamah Agung.

Apabila ditelaah pada kajian materinya, PERMA No. 2 Tahun 2012 ini mengatur tentang Pidana dan Pemidanaan yang dimana pada Pasal 15 ayat (1) Undang-Undang No. 12 Tahun 2011 menyatakan bahwa:

"Materi muatan mengenai ketentuan pidana hanya dapat dimuat dalam:

\footnotetext{
${ }^{9}$ Indonesia, Undang-Undang tentang Pembentukan Peraturan Perundang-undangan, UU No. 12 Tahun 2011, LN No. 82 Tahun 2011, TLN No. 5234 Tahun 2011, Psl. 7 ayat (2)

${ }^{10}$ Indonesia, Undang-Undang tentang Pembentukan Peraturan Perundang-undangan, UU No. 12 Tahun 2011, LN No. 82 Tahun 2011, TLN No. 5234 Tahun 2011, Psl. 8 ayat (1)

${ }^{11}$ Jimly Asshiddiqie, Perihal Perundang-undangan, Cetakan Pertama, PT. Raja Grafindo Persada, Jakarta, 2010, hlm. 13.
} 
a. Undang-Undang;

b. Peraturan Daerah Provinsi;

c. Peraturan Daerah Kabupaten/Kota". ${ }^{12}$

Sehingga berdasarkan ketentuan tersebut di atas, ada beberapa asas dalam Pembentukan Peraturan Perundang-undangan yang tidak sejalan dengan materi muatan dalam PERMA tersebut yakni:

1. kesesuaian antara jenis, hierarki, dan materi muatan;

2. dapat dilaksanakan; ${ }^{13}$

Dengan demikian, kedudukan Peraturan Mahkamah Agung No. 02 Tahun 2012 tentang Penyesuaian Penyesuaian Batasan Tindak Pidana Ringan dan Jumlah Denda Dalam KUHP secara yuridis formil sejalan dengan Undang-Undang No. 12 Tahun 2011 tentang Pembentukan Peraturan Perundang-undangan, namun secara yuridis materil mengalami kontradiksi pada asas dan muatan materinya.

\section{Dinamika Rekonstruksi Pengaturan tentang Tindak Pidana Ringan dalam Peraturan Perundang-Undangan di Indonesia.}

Usaha pembentukan KUHP Baru untuk menggantikan WvS (KUHP) yang sekarang berlaku telah cukup lama dilakukan. Dimulai dengan adanya rekomendasi Seminar Hukum Nasional I tahun 1963 yang menyerukan agar rancangan kodifikasi hukum pidana nasional selekas mungkin diselesaikan, maka pada tahun 1964 dibicarakan konsep yang pertama. Berturut-turut kemudian ada pula Konsep 1968, Konsep 1971/1972, Konsep 1982/1983 yang kemudian menjadi Konsep 1987/1988. Konsep 1987/1988 ini pun mengalami pengkajian terus-menerus sampai menjadi Konsep 1991/1992 (edisi revisi s/d Maret 1993), termasuk pula dengan perkembangan Konsep-konsep terakhir (2004 s/d 2012). ${ }^{14}$

Usaha pembaharuan KUHP warisan Belanda tersebut hingga saat ini belum juga mencapai klimaks dan membuahkan suatu kodifikasi yang berkarakter budaya bangsa Indonesia. Keadaan ini berdampak pada efektivitas beberapa aturan dalam KUHP, salah satunya adalah aturan yang mengatur tentang Tindak Pidana Ringan.

Pemerintah pada saat itu menganggap genting dan memaksa sehingga Presiden secara subyektif mengeluarkan PERPU No. 16 Tahun 1960 tentang Beberapa Peru-bahan Dalam KUHP dan PERPU No. 18 tentang Perubahan Jumlah Pidana Denda Dalam KUHP dan Ketentuan-Ketentuan Pidana Lainnya yang dikeluarkan sebelum tanggal 17 Agustus 1945 kemudian kebija-kan tersebut diapresiasi oleh legislatif dan Presiden sehingga PERPU tersebut diubah menjadi Undang-Undang No. 1 Tahun 1961 tentang Penetapan Semua Undang-Undang Darurat dan Semua Peraturan Pemerintah Pengganti Undang-Undang Yang Sudah Ada Sebelum Tanggal 1 Januari 1961 Menjadi Undang-Undang.

Pada tahun 2012, untuk memenuhi rasa keadilan masyarakat terkait propor-sionalitas penanganan tindak pidana yang nilai kerugiannya tidak seberapa, pada akhirnya Mahkamah Agung mengeluarkan Peraturan Mahkamah Agung No. 02 Tahun 2012 tentang Penyesuaian Batasan Tindak Pidana Ringan dan Jumlah Denda Dalam KUHP. Peraturan Mahkamah

\footnotetext{
${ }^{12}$ Indonesia, Undang-Undang tentang Pembentukan Peraturan Perundang-undangan, UU No. 12 Tahun 2011, LN No. 82 Tahun 2011, TLN No. 5234 Tahun 2011, Psl. 15 ayat (1)

${ }^{13}$ Indonesia, Undang-Undang tentang Pembentukan Peraturan Perundang-undangan, UU No. 12 Tahun 2011, LN No. 82 Tahun 2011, TLN No. 5234 Tahun 2011, Psl. 5 huruf c dan d

${ }^{14}$ Barda Nawawi Arief, Kebijakan Hukum Pidana, Cetakan Keempat, Kencana Prenadamedia Group, Jakarta, hlm. 102.
} 
Agung (PERMA) tersebut mengakomodir secara substansial perubahan batasan dan jumlah denda dalam KUHP serta hukum acara tindak pidana ringan. Walaupun sifat PERMA ini adalah intern regerling (pera-turan khusus/internal) namun keberlakuan substansialnya mentransformasi penegakan hukum pidana di Indonesia khususnya terhadap penanganan perkara dengan nilai kerugian di bawah Rp. 2.500.000,- (dua juta lima ratus ribu rupiah).

\section{Konsep Penyelesaian Tindak Pidana Ringan Sebelum dan Setelah Pemberlakuan Peraturan Mah-kamah Agung No. 02 Tahun 2012.}

\section{a. Penanganan Tindak Pidana Ringan Berdasarkan KUHAP.}

Penanganan tindak pidana ringan telah diatur dalam Undang-Undang Republik Indonesia No. 8 Tahun 1981 tentang Hukum Acara Pidana yang kemudian telah dikodifikasi menjadi Kitab Undang-Undang Hukum Acara Pidana. Dalam KUHAP, pemeriksaan tindak pidana ringan dilakukan dengan acara pemeriksaan cepat yang pada umumnya sama dengan dengan acara pemeriksaan biasa terkecuali yang telah diatur lain oleh Undang-Undang sebagaimana telah diatur dalam Pasal Pasal 210 KUHAP. Terhadap perkara yang nilai kerugiannya bawah Rp. 2.500.000,- (dua juta lima ratus ribu rupiah) sebelum diberlakukannya Peraturan Mahkamah Agung No. 02 Tahun 2012 tentang Penyesuaian Batasan Tindak Pidana Ringan dan Jumlah Denda Dalam KUHP, menggunakan acara pemeriksaan biasa dan pelaku/tersangka dapat dilakukan penahanan kecuali kerugiannya di bawah Rp. 250,- (dua ratus lima puluh rupiah).

\section{b. Konsep penanganan Tindak Pidana Ringan menurut Peraturan Mahkamah Agung No. 02 tahun 2012.}

Dalam PERMA tersebut secara eksplisit ditentukan bahwa:

a. Kata-kata "dua ratus lima puluh rupiah" dalam Pasal 364, 373, 379, 384, 407 ayat (1) dan 482 KUHP dibaca menjadi Rp. 2.500.000,- (dua juta lima ratus ribu rupiah). ${ }^{15}$

b. Dalam menerima pelimpahan perkara Pencurian, Penipuan, Penggelapan, Penadahan dari Penuntut Umum, Ketua Pengadilan wajib memperhatikan nilai barang atau uang yang menjadi obyek perkara dan memperhatikan ketentuan pada Pasal 1 PERMA No. 2 Tahun $2012 .^{16}$

c. Apabila nilai barang atau uang bernilai tidak lebih dari Rp. 2.500.000,- (dua juta lima ratus ribu rupiah) Ketua Pengadilan segera menetapkan Hakim Tunggal untuk memeriksa, mengadili dan memutus perkara tersebut dengan Acara Pemeriksaan Cepat yang diatur dalam Pasal $205-210$ KUHAP. ${ }^{17}$

d. Apabila terhadap terdakwa sebelumnya dikenakan penahanan, Ketua Pengadilan tidak menetapkan penahanan ataupun perpanjangan Penahanan. ${ }^{18}$

e. Tiap jumlah maksimum hukuman denda yang diancamkan dalam KUHP kecuali Pasal 303 ayat (1) dan ayat (2) , 303 bis ayat (1) dan (2), dilipatgandakan menjadi 1000 (seribu) kali. $^{19}$

\footnotetext{
${ }^{15}$ Indonesia, Peraturan Mahkamah Agung tentang Penyesuaian Batasan Tindak Pidana Ringan dan Jumlah Denda Dalam KUHP, PERMA No. 02 Tahun 2012, Psl. 1.

${ }^{16}$ Indonesia, Peraturan Mahkamah Agung tentang Penyesuaian Batasan Tindak Pidana Ringan dan Jumlah Denda Dalam KUHP, PERMA No. 02 Tahun 2012, Psl. 2 ayat (1).

${ }^{17}$ Indonesia, Peraturan Mahkamah Agung tentang Penyesuaian Batasan Tindak Pidana Ringan dan Jumlah Denda Dalam KUHP, PERMA No. 02 Tahun 2012, Psl. 2 ayat (2).

${ }^{18}$ Indonesia, Peraturan Mahkamah Agung tentang Penyesuaian Batasan Tindak Pidana Ringan dan Jumlah Denda Dalam KUHP, PERMA No. 02 Tahun 2012, Psl. 2 ayat (3)

${ }^{19}$ Indonesia, Peraturan Mahkamah Agung tentang Penyesuaian Batasan Tindak Pidana Ringan dan Jumlah Denda Dalam KUHP, PERMA No. 02 Tahun 2012, Psl.
} 
f. Dalam menangani perkara tindak pidana yang didakwa dengan pasal-pasal KUHP yang dapat dijatuhkan pidana denda, Hakim wajib memperhatikan Pasal 3 PERMA No. 2 Tahun 2012. ${ }^{20}$

Berdasarkan ketentuan-ketentuan mengenai Tindak Pidana Ringan yang telah dijabarkan secara jelas dalam PERMA tersebut di atas, maka secara subtantial penanganan Tindak Pidana Ringan pada tahap persidangan mengalami perubahan, yaitu setiap pelimpahan perkara dari Penuntut Umum yang menyangkut perkara yang nilai obyek kerugiannya di bawah Rp. 2.500.000,- (dua juta lima ratus ribu rupiah) oleh Hakim diperiksa dengan menggunakan Acara Pemeriksaan Cepat. Konsep PERMA No. 02 Tahun 2012 mentransformasi kebijakan hukum acara pidana khususnya pada tahapan kordinasi penuntut umum dalam meminta perpanjangan penahanan kepada Pengadilan Negeri tersangka/terdakwa, tahap persidangan dan pertimbangan putusan oleh Hakim.

\section{Landasan Filosofis, Sosiologis, Yuridis, dan Politis dalam Peraturan Mahkamah Agung No. 02 Tahun 2012.}

Setiap peraturan perundang-undangan wajib memuat pokok pikiran yang menjadi pertimbangan dan alasan pembentukan peraturan tersebut. Pokok pikiran tersebut berkaitan dengan lima landasan pokok bagi berlakunya norma-norma yang terkandung di dalam undang-undang tersebut bagi subjek-subjek hukum yang diatur oleh undang-undang itu. Kelima landasan dimaksud adalah landasan yang bersifat filosofis, sosiologis, politis, yuridis, dan landasan yang bersifat administratif. ${ }^{21}$ Apabila dikaji dari Sistematika Naskah Akademik, pemberlakuan PERMA No. 02 Tahun 2012 mempertimbangankan beberapa landasan, yaitu:

\section{a. Landasan Filosofis}

Konsideran dan Penjelasan Umum yang termuat dalam PERMA No. 02 Tahun 2012 menganut beberapa gagasan yang filsafati, sebagai berikut:

1) Banyaknya perkara-perkara pencurian dengan nilai barang yang kecil yang kini diadili di pengadilan cukup mendapat sorotan masyarakat. Masyarakat umumnya menilai bahwa sangatlah tidak adil jika perkara-perkara tersebut diancam dengan ancaman hukuman 5 (lima) tahun sebagaimana diatur dalam Pasal 362 KUHP oleh karena tidak sebanding dengan nilai barang yang dicurinya. ${ }^{22}$

2) Bahwa Peraturan Mahkamah Agung ini sama sekali tidak bermaksud mengubah KUHP, Mahkamah Agung hanya melakukan penyesuaian nilai uang yang sudah sangat tidak sesuai dengan kondisi sekarang ini. Hal ini dimaksudkan memudahkan penegak hukum khususnya hakim, untuk memberikan keadilan terhadap perkara yang diadilinya. ${ }^{23}$

3) Banyaknya perkara-perkara tersebut yang masuk ke pengadilan juga telah membebani pengadilan. Umumnya masyarakat tidak memehami bagaimana proses jalannya perkara pidana sampai bias masuk ke pengadilan, pihak-pihak mana saja yang memiliki kewenangan dalam setiap tahapan, dan masyarakat pun umumnya hanya mengetahui ada tidaknya suatu perkara pidana hanya pada saat perkara tersebut disidangkan di pengadilan. Dan oleh karena sudah sampai tahap persidangan di pengadilan sorotan masyarakat kemudian hanya tertuju ke pengadilan dan menuntut agar pengadilan

\footnotetext{
${ }^{20}$ Indonesia, Peraturan Mahkamah Agung tentang Penyesuaian Batasan Tindak Pidana Ringan dan Jumlah Denda Dalam KUHP, PERMA No. 02 Tahun 2012, Psl. 4.

${ }^{21}$ Jimly Asshiddiqie, Op.Cit, hlm. 117

${ }^{22}$ Indonesia, Peraturan Mahkamah Agung No. 02 Tahun 2012 tentang Penyesuaian Batasan Tindak Pidana Ringan dan Jumlah Denda Dalam KUHP, Lampiran Penjelasan Umum

${ }^{23}$ Indonesia, Peraturan Mahkamah Agung No. 02 Tahun 2012 tentang Penyesuaian Batasan Tindak Pidana Ringan dan Jumlah Denda Dalam KUHP, Pembukaan
} 
mempertimbangkan rasa keadilan masyarakat. ${ }^{24}$

4) Selain itu untuk mengefektifkan kembali pidana denda serta mengurangi beban Lembaga Pemasyarakatan yang saat ini telah banyak yang melampaui kapasitasnya yang telah menimbulkan persoalan baru, sejauh mungkin para hakim mempertimbangkan sanksi denda sebagai pilihan pemidanaan yang akan dijatuhkannya, dengan tetap mempertimbangkan berat ringannya perbuatan serta rasa keadilan masyarakat. ${ }^{25}$

Landasan filosofis merupakan pertimbangan atau alasan yang menggambarkan bahwa peraturan yang dibentuk mempertimbangkan pandangan hidup, kesadaran, dan cita-cita hukum yang meliputi suasana kebhatinan serta falsafah bangsa Indonesia yang bersumber dari Pancasila dan Pembukaan Undang-Undang Dasar Negara Republik Indonesia Tahun 1945. ${ }^{26}$ Pancasila adalah sumber dari segala sumber hukum sehingga nilai-nilai KeTuhanan, Keadilan, Kemanusiaan, dan Kerakyatan dalam setiap Pembentukan Peraturan Perundangundangan sepatutnyalah terpenuhi. Ketika suatu Peraturan Perundang-undangan sudah tidak sesuai lagi atau bahkan bertentangan dengan nilai-nilai yang terkandung dalam Pancasila dan Undang-Undang Negara Republik Indonesia Tahun 1945, maka pemerintah beserta aparatur Negara wajib melakukan perubahan atau pembaharuan terhadap Peraturan Perundangundangan tersebut.

\section{b. Landasan Yuridis}

Menurut Jimmly Asshiddiqie, landasan yuridis setiap peraturan perundang-undangan haruslah ditempatkan pada bagian Konsideran "Mengingat". ${ }^{27}$ Dalam PERMA No. 02 Tahun 2012, landasan yuridis yang dimaksud adalah sebagai berikut;

1) Pasal 24 Undang-Undang Tahun 1945 sebagaimana telah diubah dan ditambah dengan Perubahan Keempat Tahun 2002;

2) Undang-Undang No. 1 Tahun 1946 tentang Hukum Pidana;

3) Peraturan Pemerintah Pengganti Undang-Undang Nomor 16 Tahun 1960 tentang Beberapa Perubahan Dalam Kitab Undang-Undang Hukum Pidana sebagaimana telah ditetapkan dengan Undang-Undang melalui Undang-Undang Nomor 1 Tahun 1961;

4) Peraturan Pemerintah Pengganti Undang-Undang Nomor 18 Tahun 1960 tentang Perubahan Jumlah Hukuman Denda dalam Kitab Undang-Undang Hukum Pidana dan Ketentuan-Ketentuan Pidana Lainnya yang dikeluarkan Sebelum 17 Agustus 1945 sebagaimana telah ditetapkan menjadi Undang-Undang dengan Undang-Undang Nomor 1 Tahun 1961;

5) Undang-Undang No. 14 Tahun 1985 sebagaimana telah diubah dengan Undang-Undang Nomor 5 Tahun 2004 tentang Perubahan atas Undang-Undang Nomor 14 Tahun 1985 tentang Mahkamah Agung dan terakhir dengan Undang-Undang Nomor 3 Tahun 2009 tentang Perubahan Kedua atas Undang-Undang Nomor 14 Tahun 1985 tentang Mahkamah Agung;

\footnotetext{
${ }^{24}$ Indonesia, Peraturan Mahkamah Agung No. 02 Tahun 2012 tentang Penyesuaian Batasan Tindak Pidana Ringan dan Jumlah Denda Dalam KUHP, Lampiran Penjelasan Umum

${ }^{25}$ Indonesia, Peraturan Mahkamah Agung No. 02 Tahun 2012 tentang Penyesuaian Batasan Tindak Pidana Ringan dan Jumlah Denda Dalam KUHP, Lampiran Penjelasan Umum

${ }^{26}$ Indonesia, Undang-Undang tentang Pembentukan Peraturan Perundang-undangan, UU No. 12 Tahun 2011, LN No. 82 Tahun 2009, TLN No. 5234 Tahun 2011, Lampiran 1 hlm. 118.

${ }^{27}$ Jimly Asshiddiqie, Perihal Perundang-undangan, Cetakan Pertama, PT. Raja Grafindo Persada, Jakarta, 2010,
} 
6) Undang-Undang Nomor 8 Tahun 1981 tentang Hukum Acara Pidana. ${ }^{28}$

Di lain sisi, landasan yuridis menurut Amiroeddin Sjarif disebut juga landasan hukum atau dasar hukum atau legalitas adalah landasan dasar yang terdapat dalam ketentuanketentuan hukum yang lebih tinggi derajatnya. Landasan yuridis dibagi menjadi 2 (dua), yaitu:

1) Landasan yuridis yang beraspek formal (yuridis formil) yaitu ketentuan-ketentuan hukum yang memberi kewenangan kepada badan pembentuknya.

2) Landasan yuridis yang beraspek material (yuridis formil) adalah ketentuan-ketentuan hukum tentang masalah atau persoalan apa yang harus diatur. Yuridis materil dalam PERMA No. 02 Tahun 2012 yakni terkait muatan materi atau kajian substantialnya.

Apabila kita mengkaji landasan yuridis PERMA No. 02 Tahun 2012 tersebut di atas, sangatlah sistematis dan legalis. Mahkamah Agung dalam hal ini, secara yuridis formil berupaya tetap mempedomani tekhnik penyusunan peraturan perundang-undangan yang deduktif integral sebagaimana diatur dalam Undang-Undang No. 12 Tahun 2011 tentang Pembentukan Peraturan Perundang-Undangan.

\section{c. Landasan Sosiologis}

Dalam PERMA No. 02 Tahun 2012 tersurat Landasan Sosiologis Mahkamah Agung membentuk peraturan tersebut, yakni:

a. Banyaknya perkara-perkara pencurian dengan nilai barang yang kecil yang kini diadili di pengadilan cukup mendapat sorotan masyarakat. Masyarakat pada umumnya menilai bahwa sangatlah tidak adil jika perkara-perkara tersebut diancam dengan ancaman hukuman 5 (lima) tahun sebagaimana diatur dalam Pasal 362 KUHP oleh karena tidak sebanding dengan nilai barang yang dicurinya. Oleh karena itu, mengingat perkembangan kehidupan perekonomian masyarakat Indonesia yang cukup dinamis, Mahkamah Agung (MA) melakukan penyesuaian nilai rupiah terhadap pasal-pasal dalam KUHP yang mengatur juga mengenai nilai objek perkara atau pidana denda dengan melakukan penyesuaian nilai objek perkara tersebut berdasarkan harga emas yang berlaku pada sekitar tahun 1960 hingga harga emas per 3 Februari 2012 sehingga MA menetapkan kenaikkan nilai rupiah tersebut dikalikan 10.000 kali lipat. Sehingga penyesuaian ini diharapkan dapat menstabilkan kondisi hubungan sosial masyarakat Indonesia; ${ }^{29}$

b. Banyaknya perkara-perkara tersebut yang masuk ke pengadilan juga telah membebani pengadilan. Umumnya masyarakat tidak memahami bagaimana proses jalannya perkara pidana sampai bias masuk ke pengadilan, pihak-pihak mana saja yang memiliki kewenangan dalam setiap tahapan, dan masyarakat pun umumnya hanya mengetahui ada tidaknya suatu perkara pidana hanya pada saat perkara tersebut disidangkan di pengadilan. Dan oleh karena sudah sampai tahap persidangan di pengadilan sorotan masyarakat kemudian hanya tertuju ke pengadilan dan menuntut agar pengadilan mempertimbangkan rasa keadilan masyarakat. ${ }^{30}$

Kajian landasan sosiologis tersebut di atas memprioritaskan ide, cita-cita, nilai, dan

${ }^{28}$ Indonesia, Peraturan Mahkamah Agung tentang Penyesuaian Batasan Tindak Pidana Ringan dan Jumlah Denda Dalam KUHP, PERMA No. 02 Tahun 2012, Pembukaan.

${ }^{29}$ Indonesia, Peraturan Mahkamah Agung tentang Penyesuaian Batasan Tindak Pidana Ringan dan Jumlah Denda Dalam KUHP, PERMA No. 02 Tahun 2012, Lampiran Penjelasan Umum.

${ }^{30}$ Indonesia, Peraturan Mahkamah Agung tentang Penyesuaian Batasan Tindak Pidana Ringan dan Jumlah Denda Dalam KUHP, PERMA No. 02 Tahun 2012, Lampiran Penjelasan Umum. 
kebutuhan hukum masyarakat Indonesia pada saat itu.

\section{d. Landasan Politis}

Landasan Politis tereksplisit dalam PERMA No. 02 Tahun 2012, sebagai berikut:

1) Bahwa sejak tahun 1960 seluruh nilai uang yang terdapat dalam KUHP belum pernah disesuaikan kembali. Hal ini berimplikasi pada digunakannya pasal pencurian biasa yang diatur dalam Pasal 362 KUHP atas tindakan pidana yang diatur dalam Pasal 364 KUHP;

2) Bahwa apabila nilai uang yang ada dalam KUHP tersebut disesuaikan dengan kondisi saat ini maka penanganan perkara tindak pidana ringan seperti pencurian ringan, penipuan ringan penggelapan ringan dan sejenisnya dapat ditangani secara proposional mengingat ancaman hukuman paling tinggi yang dapat dijatuhkan hanyalah tiga bulan penjara, dan terhadap tersangka dan terdakwa tidak dapat dikenakan penahanan, serta acara pemeriksaan yang digunakan adalah Acara Pemeriksaan Cepat. Selain itu perkaraperkara tersebut tidak dapat diajukan upaya hukum Kasasi;

3) Bahwa materi perubahan KUHP pada dasarnya merupakan materi undang-undang, namun mengingat perubahan KUHP diperkirakan akan memakan waktu yang cukup lama sementara perkara-perkara terus masuk ke pengadilan, Mahkamah Agung memandang perlu melakukan penyesuaian nilai rupiah yang ada dalam KUHP berdasarkan harga emas yang berlaku pada tahun 1960;

4) Bahwa sejak tahun 1960 nilai rupiah telah mengalami penurunan sebesar \pm 10.000 kali jika dibandingkan dengan harga emas pada saat ini. Untuk itu maka seluruh besaran rupiah yang ada dalam KUHP kecuali pasal 303 dan 303bis perlu disesuaikan;

5) Bahwa Peraturan Mahkamah Agung ini sama sekali tidak bermaksud mengubah KUHP, Mahkamah Agung hanya melakukan penyesuaian nilai uang yang sudah sangat tidak sesuai dengan kondisi sekarang ini. Hal ini dimaksudkan memudahkan penegak hukum khususnya hakim, untuk memberikan keadilan terhadap perkara yang diadilinya; ${ }^{31}$

6. Koherensi Substantial Peraturan Mahkamah Agung No. 02 Tahun 2012 dengan Undang-Undang RI No. 12 Tahun 2011 tentang Pembentukan Peraturan Perundang-Undangan.

Apabila ditelaah dari kajian substansial pasal per pasal dalam PERMA No. 2 Tahun 2012, maka dapat digramatikalisasi inti dari isi pasal tersebut, yakni:

a. Pasal 1 mengatur tentang perubahan hukum pidana materil mengenai batasan nilai kerugian tindak pidana ringan yang telah di atur dalam KUHP dari Rp. 250,- (dua ratus lima puluh rupiah) menjadi Rp. 2.500.000,- (dua juta lima ratus ribu rupiah);

b. Pasal 2 ayat (1), (2) dan (3) mengatur tentang perubahan hukum pidana formil mengenai prosedur pelimpahan perkara oleh Ketua Pengadilan dari Penuntut Umum yang dimana Ketua Pengadilan wajib memperhatikan nilai barang atau uang yang menjadi obyek perkara dan memperhatikan ketentuan pada Pasal 1 PERMA No. 2 Tahun 2012 yang kemudian dijadikan dasar dalam menentukan bentuk Acara Pemeriksaan di persidangan dan menetapkan penahanan ataupun perpanjangan penahanan;

c. Pasal 4 mengatur tentang perubahan hukum pidana materil mengenai batasan maksimum hukuman denda yang dilipatgandakan menjadi 1000 (seribu) kali lipat dari yang diatur sebelumnya dalam KUHP kecuali pasal 303 ayat (1) dan ayat (2), 303 bis ayat (1) dan (2);

${ }^{31}$ Indonesia, Peraturan Mahkamah Agung tentang Penyesuaian Batasan Tindak Pidana Ringan dan Jumlah Denda Dalam KUHP, PERMA No. 02 Tahun 2012, Pembukaan. 
Berdasarkan interpretasi gramatikal tersebut di atas, PERMA No. 02 Tahun 2012 mengatur tentang Pidana dan Pemidanaan, sedangkan dalam Pasal 15 ayat (1) UndangUndang No. 12 Tahun 2011 menyatakan bahwa:

"Materi muatan mengenai ketentuan pidana hanya dapat dimuat dalam:

a. Undang-Undang;

b. Peraturan Daerah Provinsi;

c. Peraturan Daerah Kabupaten/Kota. ${ }^{32}$

Sehingga secara de facto PERMA No. 02 Tahun 2012 dapat meredam problematika yang terjadi dalam masyarakat, namun secara de yure PERMA No. 02 Tahun 2012 tidak memiliki korelasi atau koherensi dengan aturan di atasnya yakni Undang-Undang No. 12 Tahun 2011 tentang Pembentukan Peraturan Perundang-Undangan yang sudah barang tentu bertendensi terjadinya distorsi hukum dalam Sistem Peradilan Pidana Terpadu.

\section{Relevansi substantial Peraturan Mahkamah Agung No. 02 Tahun 2012 dengan Fungsi dan Kewenangan Mahkamah Agung.}

Sebagaimana yang telah dijelaskan pada sub-bab sebelumnya, secara substantial PERMA No. 02 Tahun 2012 mengatur tentang Pidana dan Pemidanaan sedangkan pengaturan tentang pidana dan pemidanaan oleh Undang-Undang No. 12 Tahun 2012 ditentukan bahwa perihal tersebut hanya dapat diakomodir melalalui Undang-Undang/Perpu, Peraturan Daerah Provinsi, dan Peraturan Daerah Kabupaten/Kota.

Kontradiksi terkait perihal tersebut oleh Mahkamah Agung dianggap sudah sesuai dengan tugas, fungsi dan wewenang Mahkamah Agung sebagai Lembaga Tinggi Negara. Berikut beberapa pengkajian tugas dan fungsi Mahkamah Agung:

a. Fungsi Peradilan yakni membina keseragaman dalam penerapan hukum melalui putusan kasasi dan peninjauan kembali menjaga agar semua hukum dan undang-undang diseluruh wilayah negara RI diterapkan secara adil, tepat dan benar;

b. Fungsi Pengawasan yakni melakukan pengawasan tertinggi terhadap jalannya peradilan di semua lingkungan peradilan dengan tujuan agar peradilan yang dilakukan Pengadilanpengadilan diselenggarakan dengan seksama dan wajar dengan berpedoman pada azas peradilan yang sederhana, cepat dan biaya ringan, tanpa mengurangi kebebasan Hakim dalam memeriksa dan memutuskan perkara (Pasal 4 dan Pasal 10 Undang-undang Ketentuan Pokok Kekuasaan Nomor 14 Tahun 1970);

c. Fungsi Mengatur yakni mengatur lebih lanjut hal-hal yang diperlukan bagi kelancaran penyelenggaraan peradilan apabila terdapat hal-hal yang belum cukup diatur dalam Undang-undang tentang Mahkamah Agung sebagai pelengkap untuk mengisi kekurangan atau kekosongan hukum yang diperlukan bagi kelancaran penyelenggaraan peradilan (Pasal 27 Undang-undang No.14 Tahun 1970, Pasal 79 Undang-undang No.14 Tahun 1985);

d. Fungsi Nasehat yakni memberikan nasihat-nasihat atau pertimbangan-pertimbangan dalam bidang hukum kepada Lembaga Tinggi Negara lain (Pasal 37 Undang-undang Mahkamah Agung No.14 Tahun 1985). Mahkamah Agung memberikan nasihat kepada Presiden selaku Kepala Negara dalam rangka pemberian atau penolakan grasi (Pasal 35 Undang-undang Mahkamah Agung No.14 Tahun 1985). Selanjutnya Perubahan Pertama Undang-undang Dasar Negara RI Tahun 1945 Pasal 14 Ayat (1), Mahkamah Agung

32 Indonesia, Undang-Undang tentang Pembentukan Peraturan Perundang-undangan, UU No. 12 Tahun 2011, LN No. 82 Tahun 2009, TLN No. 5234 Tahun 2011, Psl. 15 Ayat (1). 
diberikan kewenangan untuk memberikan pertimbangan kepada Presiden selaku Kepala Negara selain grasi juga rehabilitasi.

e. Fungsi Administratif yakni mengatur tugas serta tanggung jawab, susunan organisasi dan tata kerja Kepaniteraan Pengadilan (Undang-undang No. 35 Tahun 1999 tentang Perubahan Atas Undang-undang No.14 Tahun 1970 tentang Ketentuan-ketentuan Pokok Kekuasaan Kehakiman).

\section{f. Fungsi Lain-Lain}

Selain tugas pokok untuk menerima, memeriksa dan mengadili serta menyelesaikan setiap perkara yang diajukan kepadanya, berdasar Pasal 2 ayat (2) Undang-undang Nomor 14 Tahun 1970 serta Pasal 38 Undang-undang Nomor 14 Tahun 1985, Mahkamah Agung dapat diserahi tugas dan kewenangan lain berdasarkan Undang-undang. ${ }^{33}$

Merujuk pada penjabaran tugas, fungsi, dan wewenang Mahkamah Agung sebagai Lembaga Tinggi Negara tersebut di atas, dapat dikatakan bahwa secara substansial PERMA No. 2 Tahun 2012 tidak memiliki relevansi dengan tugas, fungsi, dan wewenang Mahkamah Agung karena wewenang Mahkamah Agung dalam mebuat suatu peraturan berdasarkan Undang-Undang wajib memperhatikan keutuhan sistem hukum nasional sehingga setiap aturan tetap memiliki wibawa dan hubungan antara satu dengan yang lainnya tetap harmonis.

\section{Validitas dan Keberlakuan Peraturan Mahkamah Agung No. 02 Tahun 2012 dalam Sistem Peradilan Pidana Terpadu}

Validitas adalah eksistensi norma secara spesifik. Suatu norma adalah valid merupakan suatu pernyataan yang mengasumsikan eksistensi norma tersebut dan mengasumsikan bahwa norma itu memiliki kekuatan mengikat (binding force) terhadap orang yang perilakunya diatur. Aturan adalah hukum, dan hukum yang jika valid adalah norma. Jadi hukum adalah norma yang memberikan sanksi. Elemen paksaan yang esensial dalam hukum tidak merupakan psychic compulsion, tetapi fakta bahwa sanksi sebagai tindakan spesifik ditentukan dalam kasus spesifik oleh aturan yang membentuk aturan hukum. Elemen paksaan relevan hanya sebagai bagian dari isi norma hukum, bukan sebagai suatu proses dalam pikiran individu subyek norma. Hal ini tidak dimiliki oleh sistem moralitas. Apakah orang benar-benar bertindak sesuai aturan untuk menghindari sanksi aturan hukum atau tidak, dan apakah sanksi itu sungguh dilaksanakan atau tidak, adalah masalah yang terkait dengan keberlakuan hukum. ${ }^{34}$

Walaupun validitas dan keberlakuan adalah konsep yang berbeda, namun terdapat hubungan yang penting antara keduanya. Suatu norma dikatakan valid hanya dalam hal menjadi bagian dari suatu sistem norma yang secara keseluruhan berlaku. Maka keberlakuan adalah suatu kondisi bagi validitas. ${ }^{35}$

Muatan materi PERMA No. 02 Tahun 2012 ini kemudian oleh Mahkamah Agung dianggap valid karena telah sesuai dengan tugas dan wewenang Mahkamah Agung sebagai Lembaga Tinggi Negara dan PERMA berdasarkan Undang-Undang telah menjadi bagian dalam suatu sistem norma. Validitas PERMA tersebut terbukti dengan pemberlakuan dan penerapannya di lingkungan peradilan khususnya kehakiman dan pada akhirnya dapat membendung problematika sosial yang terjadi di masyarakat terkait penanganan perkara-

\footnotetext{
${ }^{33}$ https://www.mahkamahagung.go.id/id/tugas-pokok-dan-fungsi/diakses pada hari Selasa tanggal 30 Mei 2017 pukul 06.45 Wita.

${ }^{34}$ Jimly Asshiddiqie; M. Ali Safa'at, Teori Hans Kelsen tentang Hukum, Cetakan Ketiga, Konstitusi Press, Jakarta, November 2012, hlm. 32.

${ }^{35}$ Ibid, hlm. 23.
} 
perkara ringan. Namun, keberlakuan PERMA No. 02 Tahun 2012 di lingkungan peradilan umum tidak memiliki legitimasi terhadap legal subject lainnya, seperti: Penyidik, Penuntut Umum, Tersangka, Saksi, dan Korban karena keabsahan substantial PERMA tersebut dalam Peraturan Perundang-undangan yang berlaku di Indonesia.

\section{Urgensivitas Pembentukan dan Penerapan Peraturan Mahkamah Agung No. 02 Tahun 2012.}

Pada tahun 2012, Harifin A. Tumpa, Ketua Mahkamah Agung periode 2009 s/d 2012 melakukan tindakan revolusioner dengan mengeluarkan Peraturan Mahkamah Agung 2012 tentang Penyesuaian Batasan Tindak Pidana Ringan dan Jumlah Denda Dalam KUHP. Tindakan tersebut dilakukan guna mengatasi problematika sosial yang terjadi di tengahtengah masyarakat Indonesia terkait dengan penanganan tindak pidana yang kerugiannya tidak terlalu besar namun harus menjalani proses dan hukuman yang cukup berat. Kasus pencurian 3 buah kakao oleh Nenek Minah, Pencurian Sandal Jepit dan perkara-perkara lainnya menjadi sorotan masyarakat karena penanganan terhadap perkara tersebut yang dirasa tidak proposional, tidak berkeadilan sosial, dan mencederai nilai-nilai luhur kehidupan bersama masyarakat Indonesia (Pancasila). Keadaan ini yang kemudian dianggap urgen oleh Mahkamah Agung karena keadaan tersebut berimplikasi terhadap wibawa dan integritas penegakan hukum di Indonesia. Seperti yang telah diungkapkan oleh Harifin A. Tumpa dalam Sidang Pleno Laporan Tahunan di ruang Kusumaatmadja gedung MA, pada hari Selasa 28 Februari 2012 kepada awak media, bahwa;

a. tipiring yang perlu mendapat perhatian meliputi Pasal 364, 373, 384, 407 dan 482 KUHP. Nilai denda yang tertera dalam pasal-pasal ini tidak pernah diubah negara dengan menaikkan nilai uang. "Menaikkannya sebanyak 10.000 ribu kali berdasarkan kenaikan harga emas;

b. perma ini dapat menjadi jembatan bagi para hakim sehingga mampu lebih cepat memberikan rasa keadilan bagi masyarakat terutama bagi penyelesaian tipiring sesuai dengan bobot pidananya. Perma ini juga ditujukan untuk menghindari masuknya perkara- perkara yang berpotensi mengganggu rasa keadilan yang tumbuh di tengah masyarakat dan secara tidak langsung akan membantu sistem peradilan pidana untuk kita bekerja lebih efektif dan efisien;

c. terkait dengan Perma No. 2 Tahun 2012 tentu tidak bisa dipahami sebatas teknik hukum belaka, karena ada muatan filosofis di dalamnya. Disisi lain tentu juga sebagai sinyal perlunya disegerakan penuntasan revisi terhadap KUHP dan KUHAP yang sudah memerlukan penyesuaian dengan perkembangan masyarakat; ${ }^{36}$

d. peraturan MA itu merupakan respon lembaganya terhadap tindak pidana berskala ringan yang terjadi di tengah-tengah masyarakat. MA merespons peristiwa yang terjadi di masyarakat kecil. Ada perkara kecil sampai berlarut-larut, sampai ada yang ditahan;

e. penyebab berlarut-larutnya penegakan hukum di pengadilan itu terjadi akibat KUHP tidak lagi memuat kategori Tindak Pidana Ringan (Tipiring). Tumpa mengatakan KUHP masih memuat tipiring sebagai tindak pidana berkategori di bawah Rp 250. "Sendal jepit sekarang Rp 1000 atau Rp 2000. Padahal yang dikategorikan tipiring di bawah Rp 250 perak";

f. MA sudah menunggu inisiatif dari DPR dan pemerintah merevisi KUHP terutama yang terkait Tipiring, namun tidak kunjung terealisasi hingga saat ini. Akhirnya yang

36 http://www.hukumonline.com/berita/baca/lt4f4ca3a934d9b/ma-terbitkan-perma-batasan-tindak-pidana-ringan, diakses pada hari Jumat tanggal 03 Maret 2017 pukul 16.30 Wita. 
jadi korban pengadilan. Selain itu, Harifin menyambut baik Kementerian Hukum dan HAM yang mendukung Peraturan MA disahkan menjadi undang-undang. "Kami senang sekali. Itu tujuan kami dorong pemerintah melakukan hal itu," ungkap Harifin.

g. tindak pidana ringan tetap harus diproses di pengadilan, pelaku Tipiring tidak boleh ditahan, dan tidak boleh berlarut-larut. Tipiring itu hanya ada hakim tunggal. ${ }^{37}$

Urgensivitas dikeluarkannya PERMA Tahun 2012 menjadi motivasi superior Mahkamah Agung untuk melakukan tindakan revolusioner dalam usaha pembentukan aturan pidana di Indonesia.

\section{Konsekuensi Yuridis pemberlakuan Peraturan Mahkamah Agung dalam Sistem Peradilan Pidana Terpadu.}

Secara struktural, lembaga peradilan berhubungan dengan lembaga lain, bahkan hukum itu sendiri merupakan sistem yang secara otomatis di dalamnya mengandung elemen-elemen tertentu yang berelasi dan saling mempengaruhi sehingga hukum dapat terbentuk dan terpelihara. ${ }^{38}$ Pemberlakuan PERMA No. 02 Tahun 2012 memiliki tendensi terjadinya distorsi hukum dalam Sistem Peradilan Pidana Terpadu. Sifat PERMA No. 02 Tahun 2012 sebagai intern regeling (khusus), namun pada kajian substansialnya bersifat umum, berimplikasi terhadap penangan perkara-perkara ringan pada tahapan penyidikan, penuntutan, dan persidangan. Keadaan ini sudah tentu menimbulkan konsekuensi yuridis, yaitu sebagai berikut:

a. Tidak adanya kepastian hukum terhadap aturan yang digunakan dalam penanganan perkara-perkara ringan (nilai kerugian di bawah Rp. 2.500.000,- (dua juta lima ratus rupiah) yang dapat mengikat secara utuh:

b. Ketidakharmonisan antara Penyidik, Jaksa Penuntut Umum, dan Hakim.

c. Rasa keadilan korban tidak mampu secara ekonomi akan seolah-olah dikesampingkan.

d. Multitafsir dikalangan penegak hukum.

e. Terjadinya problematika sosial dalam masyarakat mengenai pemahaman konsep Tindak Pidana Ringan.

f. Dapat menimbulkan modus operandi baru dikalangan pelaku kejahatan.

\section{Konstruksi Yuridis Restoraktif Justice Dalam Penyelesaian Tindak Pidana Ringan.}

Dalam hierarki peraturan perundang-undangan di Indonesia, Undang-Undang Dasar Negara Republik Indonesia tahun 1945 (UUD tahun 1945) adalah peraturan yang teratas (superior) kemudian barulah diikuti oleh peraturan yang berada di bawahnya yang berarti bahwa kedudukan hukum tidak tertulis yang tersurat di dalam UUD tahun 1945 sejajar dengan Undang-Undang Dasar Tahun 1945, keberadaan dan keberlakuan peraturan perundang-undangan yang berada di bawah UUD Tahun 1945 harus sejalan dengan muatan materi yang terkandung dalam UUD tahun 1945. Dalam Ketetapan MPRS No. XX/MPRS/1966 jo. Ketetapan MPR No. V/MPR/1973 dan Ketetapan MPR No. IX/MPR/1978) menyatakan bahwa:

"Sumber tertib hukum Republik Indonesia adalah pandangan hidup, kesadaran dan citacita moral yang meliputi suasana kewajiban serta watak dari bangsa Indonesia. Selanjutnya

37 http://news.okezone.com/read/2012/02/29/339/584913/alasan-ma-terbitkan-aturan-tersangka- tipiring-takditahan, diakses pada hari Jumat tanggal 03 Maret 2017 pukul 16.35 Wita.

${ }^{38}$ Eka Kartika EM, Moh., Hukum Yang Berkeadilan (Pembentukan Hukum oleh Hakim), Jurnal IUS Universitas Mataram, 2016, Vol. 4, hlm. 386. 
dikatakan bahawa cita-cita tersebut meliputi cita-cita mengenai kemerdekaan individu, kemerdekaan bangsa, peri kemanusiaan, keadilan sosial, perdamaian Nasional dan mondial, cita-cita politik mengenai sifat, bentuk dan tujuan Negara, cita-cita moral mengenai kehidupan kemasyarakatan dan keagamaan sebagai pengejawantahan dari Budi Nurani Manusia". 39

Dalam Pasal 2 Undang-Undang No. 12 Tahun 2011 berbunyi:

"Pancasila merupakan sumber segala sumber hukum Negara."

Tap. MPR, dan Pasal 2 Undang-Undang No. 12 Tahun 2011 tersebut mengisyaratkan bahwa sumber tertib hukum yang ada dan berlaku di Indonesia adalah hukum tidak tertulis yang terlembaga dalam Pancasila sehingga paham legalis yang diwariskan oleh pemerintahan zaman penjajahan Belanda dalam keadaan tertentu tidak mutlak berlaku atau dapat dianulir.

Apabila kita kembali mengkaji dasar hukum dan pedoman Penyidik POLRI dalam melakukan upaya lain terhadap penanganan perkara ringan yakni melalui prosedur non penal (musyawarah/diversi) secara komperhensif integral yang berprinsip keadilan restoratif, maka dapat dideskripsikan sebagai berikut:

1. Undang-Undang Dasar Negara Republik Indonesia Tahun 1945;

2. Undang-Undang No. 2 Tahun 2002 tentang Kepolisian Republik Indonesia (Pasal 16 Ayat (1) dan Pasal 18 Ayat (1) dan (2);

3. Nota Kesepakatan Bersama Ketua Mahkamah Agung Republik Indonesia, Menteri Hukum Dan Hak Asasi Manusia Republik Indonesia, Jaksa Agung Republik Indonesia Kepala Kepolisian Negara Republik Indonesia Tentang Pelaksanaan Penerapan Penyesuaian Batasan Tindak Pidana Ringan Dan Jumlah Denda, Acara Pemeriksaan Cepat, Serta Penerapan Keadilan Restoratif (Restorative Justice), Nomor : 131 / KMA / SKB / X / 2012 Nomor : MHH / 07.HM.03.02 Tahun 2012 Nomor : KEP-06 / E / EJP / 10 / 2012 : Nomor : B / 39 / X 2012. (pedoman)

Dalam hal perkara telah dilimpahkan kepada Penuntut Umum dan kedua belah pihak yakni korban dan tersangka pada akhirnya mencapai kesepakatan untuk berdamai, maka Penuntut Umum dapat menganulir legalitas formil yang telah berjalan dengan berdasar kepada:

1. Undang-Undang Dasar Negara Republik Indonesia Tahun 1945;

2. Kitab Undang-Undang Hukum Acara Pidana, Pasal 140 Ayat (2) huruf a;

"Dalam hal penuntut umum memutuskan untuk menghentikan penuntutan karena tidak terdapat cukup bukti atau peristiwa tersebut ternyata bukan merupakan tindak pidana atau perkara ditutup demi hukum, penuntut umum menuangkan hal tersebut dalam surat ketetapan". 40

3. Nota Kesepakatan Bersama Nomor : 131 / KMA / SKB / X / 2012 Nomor : MHH / 07.HM.03.02 Tahun 2012 Nomor : KEP-06 / E / EJP / 10 / 2012 : Nomor : B / 39 / X 2012. (sebagai pedoman).

Menurut mantan Ketua Mahkamah Agung, Bagir Manan, frase 'demi hukum' pada muatan materi Pasal 140 Ayat (2) huruf a bahwa makna rumusan tersebut sebenarnya adalah demi kepentingan tujuan hukum. Guru Besar Fakultas Hukum Universitas Padjajaran ini menyebut beberapa contoh tujuan hukum, yakni: ketertiban umum atau rasa keadilan. Bila

\footnotetext{
${ }^{39}$ Kaelan, Pancasila Yuridis Kenegaraan, Cet. Pertama, Edisi Pertama, Liberty, Yogyakarta, 1987, hlm. 25.

${ }^{40}$ Indonesia, Kitab Undang-Undang Hukum Acara Pidana, Psl. 140 Ayat (2) huruf a.
} 
kasus dipaksakan dikhawatirkan tujuan hukum itu tidak tercapai. ${ }^{41}$ Pada hakekatnya dalam keadilan diperlukan adanya keseimbangan antara kepentingan pribadi dengan kepentingan bersama. Keadilan merupakan nilai yang mutlak harus ada dalam kehidupan manusia untuk menjaga stabilitas manusia itu sendiri sebagaimana teori yang dikemukanan oleh John Rawls. $^{42}$

Konsep Diversi adalah suatu konsep untuk pengalihan suatu kasus dari peradilan formal ke peradilan informal dengan menggunakan proses Restorative Justices. ${ }^{43}$ Konsep ini sangat dekat dengan karakter hukum masyarakat Indonesia. Paradigma legalis formil mulai mengalami pergeseran menuju pendekatan legalis materil. DPR (legislatif) terus berupaya mengrekonstruksikan KUHP Nasional yang berkarakter budaya masyarakat Indonesia.

Berdasarakan konsep kontruksi yuridis terhadap penyelesaian perkara ringan yang berasaskan Keadilan Restoratif tersebut di atas, para penegak hukum sepatutnyalah memandang nilai-nilai dan kepatutan yang terlembaga dalam Pancasila dan Undang-Undang Dasar Tahun 1945 sebagai condition sine qua non dan bukan sebagai condition qum qua non, sehingga dalam penerapan dan pelaksanaannya tetap sejalan dengan cita-cita Bangsa, moral, cara pandang, dan kepatutan-kepatutan dalam masyarakat.

\section{KESIMPULAN}

Secara substantial ketentuan-ketentuan dalam PERMA No. 02 Tahun 2012 tentang Penyesuaian Batasan Tindak Pidana Ringan dan Jumlah Denda Dalam KUHP telah mengkonversi konsep Tindak Pidana Ringan yakni perkara yang diancam dengan pidana penjara atau kurungan paling lama tiga bulan dengan nilai obyek perkara di bawah $\mathrm{Rp}$. 2.500.000,- (dua juta lima ratus ribu rupiah) dan atau denda sebanyak-banyaknya tujuh juta lima ratus ribu rupiah dan penghinaan ringan. Pasal-pasal dalam KUHP yang dikonversi dalam PERMA tersebut adalah 364, 373, 379, 384, 407 ayat (1) dan 482 KUHP. Kedudukan PERMA dalam hierarki Peraturan Perundang-undangan di Indoensia adalah sebagai aturan khusus (interne regeling) karena daya ikatnya yang hanya mencakup lingkungan suatu lembaga. Secara substansial PERMA No. Tahun 2012 bertentangan dengan hukum positif yakni UU No. 12 Tahun 2011 tentang Peraturan Pembentukan Perundang-undangan karena dalam materi muatannya tersebut mengatur tentang pidana dan pemidanaan sehingga penyimpangan ini mengakibatkan PERMA No. 02 Tahun 2012 tidak memiliki kekuatan mengikat secara umum (publik). Prinsip Keadilan Restoratif melalui proses Diversi adalah sejalan dengan nilai-nilai, cita-cita hukum, moral, cara pandang, dan kepatutan-kepatutan dalam masyarakat Indonesia. Pancasila sebagai Dasar Negara dan Undang-Undang Dasar Negara Republik Indonesia tahun 1945 sebagai Dasar Hukum tertinggi sehingga legitimasi nilai-nilai luhur yang terkandung dalam Pancasila dan UUD NRI Tahun 1945 dalam Sistem Peradilan Pidana, tidak dapat dipandang sebagai condition qum qua non melainkan harus dipandang sebagai condition sine qua non.

\section{DAFTAR PUSTAKA}

$41 \quad$ http://www.hukumonline.com/berita/baca/lt4b1dea37d8cd8/menafsirkan-rumusan-demi-kepentingan-hukumdalam-kuhap/diakses pada hari Sabtu tanggal 10 Juni 2017 pukul 10.00 Wita.

\footnotetext{
${ }^{42}$ Minollah, Telaah Asas Keadilan Dalam Pemungutan Pajak Rokok, Jurnal IUS Universitas Mataram, 2017, Vol. 5, hlm. 2 .

43 Riadi, Selamet, Peran Penyidik Polri Dalam Penerapan Diversi Terhadap Anak Yang Berkonflik Dengan Hukum(Studi di PPA Polres Lombok Barat), Jurnal IUS Universitas Mataram, 2016, Vol. 4, hlm. 124.
} 


\section{Buku, Jurnal dan Artikel}

Asshiddiqie, Jimly, Perihal Undang-Undang, Cetakan Pertama, PT. Rajagrafindo Persada, Jakarta, 2010.

Asshiddiqie, Jimly \& Safa'at, Ali, Teori Hans Kelsen Tentang Hukum, Cetakan Keempat, Konstitusi Press, Jakarta, 2014.

Hamzah, Andi, Hukum Acara Pidana, Sinar Grafika, Jakarta, 2004.

Asas-Asas Hukum Pidana, Cetakan Keempat, PT. Rineka Cipta, Jakarta, 2014.

Kaelan, Pancasila Yuridis Kenegaraan, Cetakan Pertama, Liberty, Yogyakarta, 1987.

Moeljatno, Asas-asas Hukum Pidana, Cetakan Kelima, PT. Rineka Cipta, Jakarta, 1993.

Nawawi Arief, Barda, Kebijakan Hukum Pidana (Perkembangan Penyusunan Konsep KUHP Baru), Cetakan Keempat, Kencana Prenadamedia Group, Jakarta, 2014.

, Kapita Selekta Hukum Pidana tentang Sistem Peradilan Pidana Terpadu, BP Univ. Diponegoro, Semarang, 2007.

Soesilo, R., Kitab Undang-Undang Hukum Pidana (KUHP) Serta KomentarKomentarnya Lengkap Pasal Demi Pasal, Politeia, Bogor, 1994.

Zainal Asikin, Mengenal Filsafat Hukum, Cetakan I, Pustaka Reka Cipta, Bandung, 2014.

Amiruddin, Keabsahan Perubahan dan Penambahan Peraturan Hukum Pidana melalui PERPPU Dan PERMA, ARENA HUKUM Volume 6, Nomor 3, Universitas Mataram, 2012, hlm. 156.

Eka Kartika EM, Moh., Hukum Yang Berkeadilan (Pembentukan Hukum oleh Hakim), Jurnal IUS Universitas Mataram, 2016, Vol. 4, hlm. 386

Minollah, Telaah Asas Keadilan Dalam Pemungutan Pajak Rokok, Jurnal IUS Universitas Mataram, 2017, Vol. 5, hlm. 2.

Riadi, Selamet, Peran Penyidik Polri Dalam Penerapan Diversi Terhadap Anak Yang Berkonflik Dengan Hukum(Studi di PPA Polres Lombok Barat), Jurnal IUS Universitas Mataram, 2016, Vol. 4, hlm. 124.

\section{Peraturan-Peraturan}

Indonesia, Undang-Undang Dasar Republik Indonesia Tahun 1945.

Indonesia, Ketetapan Majelis Permusyawaratan Rakyat Republik Indonesia No. : VI/MPR/2011 Tahun 2001 tentang Etika Kehidupan Berbangsa.

Indonesia, Peraturan Pemerintah Pengganti Undang-Undang (Perpu) Nomor 16 Tahun 1960 Tentang Beberapa Perubahan Dalam Kitab Undang-Undang Hukum Pidana, LN. No. 50 Tahun 1960, TLN. No. 1976.

Indonesia, Kitab Undang-Undang Hukum Pidana.

Indonesia, Undang-Undang No. 8 Tahun 1981 tentang Kitab Undang-Undang Hukum Acara Pidana, LN. No. 76 Tahun1981, TLN. No. 3209.

Indonesia, Undang-undang No. 12 Tahun 2011 tentang Pembentukan Peraturan Perundang-undangan. 
Indonesia, Undang-Undang No. 14 Tahun 1985 tentang Mahkamah Agung, LN. No. 73 Tahun1985, TLN. No. 3316. sebagaimana telah diubah oleh Undang-Undang No. 3 Tahun 2009 tentang Perubahan Undang-Undang No. 14 Tahun 1985 tentang Mahkamah Agung, LN. No. 3 Tahun 2009.

Indonesia, Undang-Undang No. 48 Tahun 2009 tentang Kekuasaan Kehakiman, Peraturan Mahkamah Agung No. 2 Tahun 2012. LN. No. 157 Tahun 2009, TLN. No. 5076.

Indonesia, Undang-Undang No. 2 Tahun 2002 tentang Kepolisian Republik Indonesia.

Indonesia, Undang-Undang No. 18 Tahun 2005 tentang Komisi Kejaksaan.

Indonesia, Peraturan Mahkamah Agung No. 2 Tahun 2012 tentang Penyesuaian Batasan Tindak Pidana Ringan dan Jumlah Denda dalam KUHP.

Putusan Pengadilan Negeri Stabat, Sumatera Utara, nomor : 239/Pid.B/2015/PN.Stb

\section{Sumber Lain}

Kamus Hukum Ensiklopedia

http://news.detik.com/read/2009/11/19/152435/1244955/10/mencuri-3-buah-kakaonenek-minah-dihukum-1-bulan-15-hari, diakses pada hari Jumat tanggal 26 September 2014 pukul 15.35 WITA.

http://news.detik.com/read/2012/01/05/040629/1807006/10/kasus-pencurian-sandalorang-tua-diharapkan-mampu-membina-aal, diakses pada hari Jumat tanggal 26 September 2014 pukul 15.40 WITA.

http://foto.liputan6.com/show/1/23029/0/terdakwa-kasus-pencurian-enam-buah-piringrasminah-60-di-pn-tangerang-banten-dalam-sidang-ini-penasehat-hukummenghadirkan-5-saksi-antara, diakses pada hari Jumat tanggal 26 September 2014 pukul 15.42 WITA.

http://www.tempo.co/read/news/2012/01/11/058376741/Kakek-Pencuri-SegenggamMerica-Diadili, diakses pada hari Jumat tanggal 26 September 2014 pukul 15.43 WITA.

https://id.wikipedia.org/wiki/Eksistensi, diakses pada hari Rabu tanggal 01 Maret 2017 pukul 10.10 Wita.

http://news.detik.com/berita/2914348/kasus-pencurian-rp-41-ribu-pelaku-dibui-danjaksa-abaikan-perma, diakses pada hari Jumat tanggal 03 Maret 2017 pukul 16.30 Wita.

http://news.detik.com/berita/2914348/kasus-pencurian-rp-41-ribu-pelaku-dibui-danjaksa-abaikan-perma; diakses pada hari Jumat tanggal 03 Maret 2017 pukul 16.35 Wita

http://www.hukumonline.com/berita/baca/lt4f4ca3a934d9b/ma-terbitkan-perma-batasantindak-pidana-ringan; diakses pada hari Jumat tanggal 03 Maret 2017 pukul 16.40 Wita

http://news.okezone.com/read/2012/02/29/339/584913/alasan-ma-terbitkan-aturan-tersangkatipiring-tak-ditahan, diakses pada hari Jumat tanggal 03 Maret 2017 pukul 16.50 Wita 